\title{
Mood stabilizers: Balancing tolerability, serum levels, and dosage
}

Jessa Koch, PharmD, BCPP

$\mathrm{M}$ r. B, age 32 , was diagnosed with bipolar disorder 10 years ago after experiencing a manic episode that resulted in his first psychiatric hospitalization. He was prescribed quetiapine, $400 \mathrm{mg} / \mathrm{d}$, and remained stable for the next several years. Unfortunately, Mr. B developed significant metabolic adverse effects, including diabetes and a 30-pound weight gain, so he was switched from quetiapine to lithium. Mr. B was unable to tolerate the sedation and cognitive effects of lithium, and the dose could not be titrated to within the therapeutic window. As a result, Mr. B experienced a moderate depressive episode. His current clinician would like to initiate lamotrigine at a starting dose of $25 \mathrm{mg} / \mathrm{d}$. Mr. B has not had a manic episode since the index hospitalization, and this is his first depressive episode.

The term "mood stabilizer" has come to refer to medications that treat a depressive and/or manic episode without inducing the other. In conventional terms, it refers to non-antipsychotic medications such as lithium, divalproex, and lamotrigine. Except for lithium, mood stabilizers are also antiepileptic drugs (AEDs). The role of AEDs for treating psychiatric conditions was discovered after they were originally FDAapproved for treating seizures. Following

Dr. Koch is Assistant Professor of Pharmacy Practice, Loma Linda University School of Pharmacy, Loma Linda, California.

Disclosure

The author reports no financial relationships with any companies whose products are mentioned in this article, or with manufacturers of competing products.

doi: $10.12788 /$ cp. 0147

this discovery, the recommended doses and therapeutic ranges for these agents when applied to psychiatric treatment fell into a gray area.

Every patient is different and requires an individualized treatment plan, but this often leaves the clinician wondering, "How high is too high for this mood stabilizer?" or "My patient is responding well, but could a higher dose be even more effective?" In the case of Mr. B, who has trialed 2 medications with poor tolerability, how high can the lamotrigine dose be titrated to achieve a therapeutic response without adverse effects? The literature on this topic does not provide an exact answer, but does shed some light on key considerations for such decisions.

\section{Which mood stabilizers are recommended?}

One of the most recently updated guidelines for the treatment of bipolar disorder was

\section{Practice Points \\ - Use the therapeutic levels for lithium and divalproex for safety purposes and as a guide for patient specific therapeutic response. Treat the patient, and do not focus solely on targeting a level.}

- The maximum recommended dose of divalproex is $60 \mathrm{mg} / \mathbf{k g} / \mathrm{d}$, which greatly exceeds the doses typically used in psychiatric practice.

- The maximum dose of lamotrigine is $400 \mathbf{~ m g} / \mathrm{d}$, but studies have found that lower doses are effective for treating bipolar disorder.

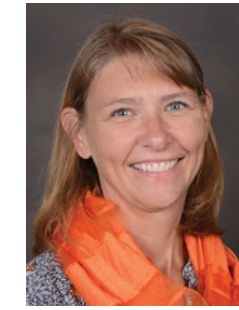

Vicki L. Ellingrod, PharmD, FCCP Department Editor
Savry Psychopharmacology is produced in partnership with the College of Psychiatric and Neurologic Pharmacists cpnp.org mhc.cpnp.org (journal) 


\section{Clinical Point}

Lithium, divalproex, and lamotrigine are each recommended as first-line options for treating bipolar disorder

Discuss this article at www.facebook.com/ MDedgePsychiatry

\section{Table 1}

\section{Mood stabilizer dosing strategies and therapeutic serum levels}

\begin{tabular}{|c|c|c|c|}
\hline Agent & Dosing & Therapeutic serum levels & Time to obtain levels \\
\hline Lithium & $\begin{array}{l}\text { Start: } 300 \mathrm{mg} \text { twice daily } \\
\text { to } 300 \mathrm{mg} 3 \text { times daily } \\
\text { Usual dose: } 900 \text { to } \\
1,800 \mathrm{mg} / \mathrm{d}\end{array}$ & $\begin{array}{l}\text { Depression: } 0.4 \text { to } 0.8 \mathrm{mEq} / \mathrm{L} \\
\text { Mania: } 0.6 \text { to } 1.0 \mathrm{mEq} / \mathrm{L}\end{array}$ & $\begin{array}{l}\text { Initial trough level should } \\
\text { be obtained no earlier than } \\
5 \text { days after dose initiation } \\
\text { or dose changes }\end{array}$ \\
\hline Divalproex & $\begin{array}{l}\text { Load: } 20 \text { to } 30 \mathrm{mg} / \mathrm{kg} / \mathrm{d} \\
\text { Maximum dose: } \\
60 \mathrm{mg} / \mathrm{kg} / \mathrm{d}\end{array}$ & 50 to $125 \mu \mathrm{g} / \mathrm{mL}$ & $\begin{array}{l}\text { Initial trough level should } \\
\text { be obtained no earlier than } \\
3 \text { days after dose initiation } \\
\text { or dose changes }\end{array}$ \\
\hline Lamotrigine & $\begin{array}{l}\text { Slow titration requireda: } \\
\text { Weeks } 1 \text { to } 2: 25 \mathrm{mg} / \mathrm{d} \\
\text { Weeks } 3 \text { to } 4: 50 \mathrm{mg} / \mathrm{d} \\
\text { Week } 5: 100 \mathrm{mg} / \mathrm{d} \\
\text { Week 6: } 200 \mathrm{mg} / \mathrm{d} \\
\text { Maximum dose: } \\
400 \mathrm{mg} / \mathrm{d}\end{array}$ & 3,000 to $14,000 \mathrm{ng} / \mathrm{mL}^{\mathrm{b}}$ & $\begin{array}{l}\text { Therapeutic monitoring } \\
\text { not required. If trough level } \\
\text { desired, level should be } \\
\text { drawn no sooner than } \\
5 \text { days after dose changes }\end{array}$ \\
\hline
\end{tabular}

released in 2018 by the Canadian Network for Mood and Anxiety Treatments (CANMAT). ${ }^{1}$ Lithium, divalproex, and lamotrigine were each recommended as a first-line option for treating bipolar disorder. For lithium and divalproex, the CANMAT guidelines recommend serum level monitoring for efficacy and tolerability; however, they do not recommend serum level monitoring for lamotrigine. Lithium and divalproex each have safety and tolerability concerns, particularly when selected for maintenance therapy, whereas lamotrigine is typically much better tolerated. ${ }^{1}$ Divalproex and lithium can cause weight gain, gastrointestinal adverse effects (nausea, vomiting, diarrhea), and tremor. Additional tolerability concerns with lithium include renal toxicity, electrocardiogram abnormalities, hypothyroidism, cognitive impairment, and dermatologic reactions. Divalproex can produce greater levels of sedation and may impact reproductive function (oligomenorrhea or hyperandrogenism). One of the most common adverse effects of lamotrigine is a nonserious rash; however, slow dose titration is necessary to decrease the risk of a serious, life-threatening rash such as StevensJohnson syndrome.

\section{Lithium}

Lithium continues to be regarded as a goldstandard therapy for bipolar disorder. The exact serum levels corresponding to efficacy and tolerability vary. The Lithiumeter: Version 2.0 is a schematic that incorporates the various levels recommended by different clinical guidelines. ${ }^{2}$ The recommended serum levels range from 0.6 to $1.0 \mathrm{mEq} / \mathrm{L}$ for mania and 0.4 to $0.8 \mathrm{mEq} / \mathrm{L}$ for depression. ${ }^{2}$ One of the main issues with lithium dosing is balancing a therapeutic level with tolerability and toxicity. Toxicity may begin when lithium levels exceed $1.2 \mathrm{mEq} / \mathrm{L}$, and levels $>2.0 \mathrm{mEq} / \mathrm{L}$ can be lethal. Signs of acute toxicity include tremor, headache, arrhythmia, nausea, vomiting, diarrhea, polyuria, and polydipsia. Conversely, chronic lithium use may lead to chronic toxicity as patients age and their physical health changes. Signs of chronic toxicity include ataxia, confusion, renal dysfunction, and tremor. There is no "one size fits all" when it comes to lithium 


\section{Signs and symptoms of lithium toxicity}

\begin{tabular}{l|l} 
Agent & Signs and symptom \\
\hline Lithium & $\begin{array}{l}\text { Worsening of adverse effects such as headache, fatigue, nausea, vomiting, diarrhea, } \\
\text { polyuria, polydipsia, tremor, polydipsia, arrhythmia } \\
\text { Severe toxicity: seizures, coma, ataxia, nystagmus, myoclonic jerks, confusion, } \\
\text { disorientation, cardiac toxicity }\end{array}$ \\
\hline Source: Reference 2
\end{tabular}

Strategies for managing adverse effects of lithium and divalproex ${ }^{a}$

\begin{tabular}{|c|c|c|}
\hline Agent & Adverse effects & Management strategies \\
\hline \multirow[t]{8}{*}{ Lithium } & Acne & $\begin{array}{l}\text { Decrease dose, conventional dermatologic } \\
\text { treatments }\end{array}$ \\
\hline & Polydipsia/polyuria & $\begin{array}{l}\text { Avoid dehydration, lower the dose, consolidate to } \\
\text { bedtime }\end{array}$ \\
\hline & Weight gain & Increase exercise, monitor diet \\
\hline & Intentional hand tremor & $\begin{array}{l}\text { Divide dose, change to sustained release formulation, } \\
\text { add propranolol }\end{array}$ \\
\hline & $\begin{array}{l}\text { Gastrointestinal upset (nausea, } \\
\text { vomiting, diarrhea) }\end{array}$ & $\begin{array}{l}\text { Take with food, change to sustained release } \\
\text { formulation, divide dose }\end{array}$ \\
\hline & Lethargy & Consolidate dose to bedtime \\
\hline & Leukocytosis & Monitor for signs of infection \\
\hline & Hypothyroidism & Monitor and add thyroid supplementation if indicated \\
\hline \multirow[t]{4}{*}{ Divalproex } & Somnolence/fatigue & Dose at bedtime \\
\hline & Thrombocytopenia & Lower dose \\
\hline & Alopecia & Lower dose \\
\hline & Weight gain & Increase exercise, monitor diet \\
\hline
\end{tabular}

dosing. Individualized dosing is necessary to balance efficacy and tolerability.

\section{Divalproex}

Divalproex was initially studied for use as an AED, and its therapeutic levels as an AED are not the same as those indicated for bipolar disorder. Generally, patients with bipolar disorder require a divalproex serum level $>50 \mu \mathrm{g} / \mathrm{mL}$. Ranges closer to $100 \mu \mathrm{g} /$ $\mathrm{mL}$ have been found to be most effective for treating acute mania. ${ }^{3}$ A loading dose of 20 to $30 \mathrm{mg} / \mathrm{kg} / \mathrm{d}$ can be administered to help achieve mood stabilization. Again, efficacy must be balanced against toxicity. The maximum dose of divalproex is $60 \mathrm{mg} / \mathrm{kg} / \mathrm{d}$, which is rarely seen in psychiatric practice. Early studies of divalproex found adverse effects greatest in individuals with plasma levels $>100 \mu \mathrm{g} / \mathrm{mL}$. Reported adverse effects included alopecia, weight gain, tremor, and mental status changes. ${ }^{4}$

\section{Lamotrigine}

Unlike lithium and divalproex, lamotrigine therapeutic drug monitoring is not common. The accepted therapeutic reference range (TRR) for lamotrigine as an AED is 3,000 to $14,000 \mathrm{ng} / \mathrm{mL}$. Unholzer et $\mathrm{al}^{5}$ evaluated the dose and TRR for individuals with bipolar disorder treated with lamotrigine. No statistically significant difference in lamotrigine serum levels was found in responders vs nonresponders. ${ }^{5}$ Most patients were prescribed $\leq 200 \mathrm{mg} / \mathrm{d}$; however, some were prescribed higher doses. The maximum dose

\section{Clinical Point \\ Toxicity may begin when lithium levels exceed $1.2 \mathrm{mEq} / \mathrm{L}$, and levels $>2.0$ $\mathrm{mEq} / \mathrm{L}$ can be fatal}




\section{Clinical Point}

\section{The therapeutic window of lamotrigine is less narrow than that of lithium or divalproex}

\section{Related Resource}

- Goldberg JF, Ernst CL. Managing the side effects of psychotropic medications. 2nd ed. American Psychiatric Association Publishing; 2019.

Drug Brand Names

\begin{tabular}{ll}
\hline Divalproex sodium/valproic & Lamotrigine - Lamictal \\
acid.Depakote & Quetiapine -Seroquel
\end{tabular}

Lithium • Eskalith, Lithobid

recommended when lamotrigine is used as an AED is $400 \mathrm{mg} / \mathrm{d}$; however, this study furthered the evidence that lower doses tend to be effective in bipolar disorder.

\section{CASE CONTINUED}

It has been 3 months since Mr. B was initiated on lamotrigine, and he has since been titrated to his current, stable dose of $100 \mathrm{mg} / \mathrm{d}$. Mr. B is no longer experiencing the sedation he had with lithium and has the energy to commit to an exercise routine. This has allowed him to lose 15 pounds so far and greatly improve control of his diabetes.

\section{Dosage summary}

Most available evidence supports dosing lithium and divalproex to effect, typically seen between 0.6 to $1.0 \mathrm{mEq} / \mathrm{L}$ and 50 to $125 \mu \mathrm{g} / \mathrm{mL}$, respectively. Higher plasma levels tend to correspond to more adverse effects and toxicity. Lamotrigine does not have such a narrow therapeutic window. Lamotrigine for psychiatric treatment yields greatest efficacy at approximately $200 \mathrm{mg} / \mathrm{d}$, but doses can be increased if warranted, which could be the case in Mr. B.

Table $1^{1-5}$ (page 38 ) outlines dosing strategies and therapeutic serum levels for lithium, divalproex, and lamotrigine. Table $2^{2}$ (page 39) lists signs and symptoms of lithium toxicity, and Table $3^{1,2}$ (page 39) describes strategies for managing adverse effects of lithium and divalproex.

\section{References}

1. Yatham LN, Kennedy SH, Parikh SV, et al. Canadian Network for Mood and Anxiety Treatments (CANMAT) and International Society for Bipolar Disorders (ISBD) 2018 guidelines for the management of patients with bipolar disorder. Bipolar Disord. 2018;20(2):97-170.

2. Malhi GS, Gershon S, Outhred T. Lithiumeter: version 2.0 . Bipolar Disord. 2016;18(8):631-641.

3. Allen MH, Hirschfeld RM, Wozniak PJ, et al. Linear relationship of valproate serum concentration to response and optimal serum levels for acute mania. Am J Psychiatry. 2006;163(2) 272-275.

4. Turnbull DM, Rawlins MD, Weightman D, et al. Plasma concentrations of sodium valproate: their clinical value. Ann Neurol. 1983;14(1):38-42.

5. Unholzer S, Haen E. Retrospective analysis of therapeutic drug monitoring data for treatment of bipolar disorder with lamotrigine. Pharmacopsychiatry. 2015;48(7):296. 